It is certain that other industries which use electricity intensively will ask for the same treatment; the British Steel Corporation is an obvious candidate. Not the least of the difficulties is finding out what the terms of the contracts are: as $\mathrm{Mr}$ Anthony Crosland, President of the Board of Trade, said in the House of Commons, "I cannot tell him (the Hon. Member) the price. It is never revealed in contracts of this kind. I can assure him, however, that it is completely unsubsidized". The Government is already covering itself against claims from other users by saying that the demand must be "substantially new" or evidence must be produced that existing operations are becoming uneconomic. But this is no more than inventing principles to suit policies. Even the parlous state of the British balance of payments (which is at last showing signs of recovery) can hardly be held to justify such an arbitrary way of doing things.

\section{Data Processing Delayed}

THE Post Office plan to promote the use of computers by creating a National Data Processing Service (NDPS) seems to be barely off the ground, although the Bill giving the Post Office power to provide the data processing service became law last year. It is true that at the beginning of the current financial year the National Data Processing Service became a selfaccounting unit within the Post Office, but so far it has only one outside customer-the Customs and Excise Department, which is planning to start using the service in the early 1970 s to help with the documentation involved in the importation of goods through London Airport.

The philosophy behind the NDPS is that, by 1971 , the Post Office will have as many as twenty large computers. Several of the machines are for special applications, the control of the aerials at Goonhilly, for example, or will be part of the Giro banking system, but a number of the computers earmarked for commercial purposes within the Post Office are also suitable for use in the data processing system. The form the service will take has still not been publicized, but it seems there will be some flexibility to meet the needs of customers. Both on-line and off-line data processing will be provided.

Just now, the Post Office seems to be keeping quiet about the service, no doubt because at present its computers are heavily committed to Post Office work. Like all computer users, it is finding a shortage of experienced personnel; nevertheless it is reaching its target of 100 recruits a year to train as computer operators. Some of the delay in setting up the NDPS may also have its roots in the problem of starting the Giro system, itself ambitious enough.

\section{Contraception in South America}

IN his recent encyclical, the Popc has forbidden all forms of birth control with the exception of the so-called natural rhythm method. The prohibition covers all means of contraception, as well as abortion and sterilization. The burden of the Pope's sentiments is likely to be borne most heavily in Latin America, a predominantly Roman Catholic continent. How will the encyclical be received in Latin American countries?

Official policies towards birth control in Latin
America are a reaction to the peoples' manifest desire to limit their fertility. Given the attitude of the Church and state, this desire has to be expressed in the form of abortions, which have now reached epidemic proportions in some Latin American countries. In Chile, according to a statement by the Minister of Public Health, there is one illegal abortion for every two live births. In 1965,20 per cent of the beds in Chilean maternity hospitals were filled with patients suffering from the effects of illegal abortions, and 39 per cent of maternal deaths were due to the same cause. The abortion rate for Latin America as a whole is estimated to amount to between 25 and 30 per cent of all live births. The Chilean Government has perhaps been the most sensitive to suffering inflicted by official policies, and last year the Minister of Health announced a family planning campaign-a courageous step for a Christian-democrat administration. The minister referred to the abortion statistics to justify this change of policy and said that family planning advice would be made available to married couples, particularly those in the lower-income groups, with the hope of reducing the number of abortions.

The Chilean lead has been followed by a number of other Latin American governments; family planning units, either allowed or sponsored by the governments concerned, are operating or about to operate in the Argentine, Bolivia, Brazil, Colombia, Dominica and Ecuador. The effects of the Pope's encyclical are most to be feared at the governmental level. For the individual, it is plain that the Church's doctrines on birth control are widely ignored. Abortion is a graver Roman Catholic sin than contraception. Governments, however, may feel stronger pressure from the Roman Catholic hierarchy to abandon the family planning campaigns they have begun.

Another spectre raised by the Pope's encyclical is that the World Health Organization may be denied its eminently proper and necessary interest in birth control. Proposals that the WHO should advocate birth control have several times been frustrated by its delegates from Catholic countries and only recently have they withdrawn their opposition. It is conceivable that these delegates may be re-instructed.

\section{Biggest Broker Yet}

As part of the deal by which Rolls-Royce obtained the contract to supply engines for the Lockhced 1011 airbus, Air Holdings, a British holding company, became one of the world's largest brokers of aireraft. Rolls-Royce, to overcome Congressional fears about the adverse effects on the American balance of payments of buying British engines for American aircraft, had to lay on a substantial export order for the 1011 . Through the offices of Lord Poole and his friends in the city and in Air Holdings, that company placed a firm order for thirty of the airbuses with an option on twenty more. This by all accounts is an entirely private speculation. On the face of things at least Air Holdings is planning to finance the operation from its own resources. It has bought the aircraft at a launching price, somewhere between $\$ 15$ million and $\$ 20$ million apiece, and hopes that by 1973, when it takes delivery of the first of its aircraft, the going price will be higher and the market unsaturated. 
Rolls-Royce, of course, is sitting pretty whatever happens; 168 Lockheed airbuses have been ordered so far, a record start for any commercial airliner, and Rolls-Royce will be supplying at least three engines worth $\$ 2.5$ million each for every one. Air Holdings, on the other hand, will, by 1973 , be getting one airbus a month and so far it has not sold any. When it comes to selling, Air Holdings is, of course, entirely dependent on the technical backing of Rolls-Royce and Lockheed engineers, but, faced with the prospect of holding thirty aircraft worth some $\$ 600$ million and no government aid, it is remarkably cheerful. It has been agreed that all the initial sales of the 1011 in the rest of the world, apart from the United States and countries to which the United States would refuse to sell the aircraft for political reasons, will be made by Air Holdings. With the European airbus not even off the council tables, let alone the drawing board and the ground-on Friday there is to be yet another crucial ministerial meetingthe 1011 has two competitors. One is the DC 10 , ordered by United and American airlines in the United States and powered by a General Electric engine which is a commercial adaptation of the engine developed for the C5A military transport. The other is the Boeing 747. The four-engined Boeing is, strictly speaking, a long haul aircraft capable of carrying five hundred people and the smaller and shorter ranged Lockheed should be better suited for the European routes. It should also be at an advantage over its direct competitor, the $\mathrm{DC} 10$. It is no secret that all the American domestic airlines would have preferred to have aircraft powered by the Rolls-Royce engine. In the world market, free from buy-American lobbies, that should prove to be Air Holdings' best selling point.

\section{Imperial Demise}

THE prospect of beer by the litre for British drinkers came a step closer last week. Mr Anthony Wedgwood Benn, the Minister of Technology, announced that the United Kingdom is to adopt the metric system of measurement by 1975-the target date already accepted by British industry for its timetable. The minister has accepted all the recommendations of the Standing Joint Committee on Metrication, which published a long-awaited report on July 26 . The report says that a Metrication Board should be set up to organize the change, which should begin in 1971. Although these recommendations were widely anticipated (it was the Confederation of British Industry which first came forward with the suggestion for the Metrication Board), the Government's decision is nevertheless welcome. The industrial change is going ahead fast--two weeks ago the British Standards Institution published the final programme for the engineering industry-but the non-industrial sector of the economy and the general public have been lagging behind. The establishment of the Metrication Board will at least provide a chance for publicity, even if the coordinating function of the board remains somewhat nebulous.

The report makes it clear that there is not much time to waste. It is "imperative" for the planning of the change in the general sectors of the economy to be put in hand; if this is not done, "the dynamism of the industrial change will be lost". In order to have enabling legislation on the statute book by January 1, 1971, a Bill will have to be introduced in the Parlia- mentary session 1969-70. The programme will allow for a good deal of flexibility - some sectors will finish before 1975, some after. In the schools, the emphasis should shift from imperial to metric units by 1969 , although major imperial units will continue to be taught for a few years after that.

The report dodges the difficult problem of producing a balance sheet for the change. "Both the benefits and costs of metrication are virtually impossible to quantify even for a single industrial concern." Nevertheless, the Government has asked the Metrication Board, when it is set up, to produce a sector by sector appreciation of the problems, including the costs involved. The cost-effectiveness of metrication is not therefore likely to be known until it is a fact. So far, certainly, hunch has played a greater part than has a sober analysis of the situation.

Reaction so far to the minister's announcement has been muted. Only one organization, the Business Equipment Trade Association-faced with greater costs than others-has made disapproving noises. The public still seems hardly aware of the revolution that is to overtake it-decimal coins by 1971, metric units by 1975 . This is clearly an unsatisfactory state of affairs, and the Metrication Board would do well to try to encourage discussion of the change, if only to condition the public. The report does open the door, if only a fraction, to those who feel the change is an intolerable burden. It says that the Metrication Board should be responsible for making recommendations to the Government on special cases of hardship which might merit consideration for compensation. Mr Benn seems not to accept this argument; his statement said "There can be no question of compensation; the costs of adopting metric weights and measures must lie where they fall." But if the board does start to consider compensation, the number of protesters is likely to increase as if by magic.

\section{Up in the Air}

SINCE the British order for F111 aircraft was cancelled, and Anglo-French collaboration on the variable geometry aircraft broke down, the Royal Air Force has been without an advanced combat aircraft suitable for the middle and late seventies. For some months, however, discussions have been in progress between the British Government and the Governments of Belgium, Canada, West Germany, Italy and the Netherlands. These came to a head two weeks ago in Bonn, when four of the governments signed an agreed memorandum which takes them one step further towards the building of a joint strike-reconnaissance aircraft for the seventies. Although Belgium and Canada have not so far signed the memorandum, it is thought possible that they may join in later, as the project definition stage advances.

It is easy to make fun of international projects like these, with their continual horse-trading over design leadership and their apparent inability to move beyond paperwork. But there are some reasons to believe that this project may have better fortune than its predecessors. Certainly it is becoming increasingly urgent for Britain and some of the other countries involved to find a successor to their existing aircraft. All the air forces involved, except Britain's, fly the United States F104 Starfighter aircraft, which has had 